\title{
Occupational Noise Levels in Two Fish Rearing Buildings at an Aquaculture Facility
}

\author{
Jill Voorhees' ${ }^{1}$ Michael E. Barnes ${ }^{2}$ \\ ${ }^{1}$ South Dakota Department of Game, Fish and Parks, Cleghorn Springs State Fish Hatchery, Rapid City, USA \\ ${ }^{2}$ South Dakota Department of Game, Fish and Parks, McNenny State Fish Hatchery, Spearfish, USA \\ Email: mike.barnes@state.sd.us
}

How to cite this paper: Voorhees, J., and Barnes, M.E. (2017) Occupational Noise Levels in Two Fish Rearing Buildings at an Aquaculture Facility. Occupational Diseases and Environmental Medicine, 5, 58-66. https://doi.org/10.4236/odem.2017.52006

Received: May 2, 2017

Accepted: May 22, 2017

Published: May 27, 2017

Copyright ( 92017 by authors and Scientific Research Publishing Inc. This work is licensed under the Creative Commons Attribution International License (CC BY 4.0).

http://creativecommons.org/licenses/by/4.0/

\section{cc) (i) Open Access}

\begin{abstract}
Occupational noise is commonly encountered during aquaculture. This study documented noise levels in two buildings at a production fish hatchery, a tank room with $32,1.8-\mathrm{m}$ diameter tanks, and a rearing pavilion with $32,6.1-\mathrm{m}$ diameter tanks. With water flowing to all of the tanks in the tank room, mean noise levels were $68.4 \mathrm{~dB}$, and significantly increased to $73.0 \mathrm{~dB}$ during tank cleaning and $73.2 \mathrm{~dB}$ when intermittent automatic feeders were running. The highest tank room values of $77.1 \mathrm{~dB}$ were recorded directly next to individual tanks during cleaning. With water flowing to all of the tanks in the rearing pavilion, mean noise levels were $70.2 \mathrm{~dB}$. A significant increase to $76.1 \mathrm{~dB}$ was observed when the pavilion tanks were being power washed, with the highest value of $83.2 \mathrm{~dB}$ recorded immediately adjacent to the power washer. Although none of the noise levels exceeded regulatory limits, the use of techniques to reduce occupational noise in aquaculture environments is recommended.
\end{abstract}

\section{Keywords}

Noise, Aquaculture, Fish Hatchery, Tanks, Water Flow

\section{Introduction}

Workplace exposure to high noise levels is a serious issue. In the United States, an estimated 9 million workers have been exposed to hazardous sound levels [1]. With the constant movement of water typically required during intensive aquaculture operations, occupational noise is a definite health risk [2]. However, it has received attention from only a limited number of studies [2] [3] [4] [5] [6].

An 8-hour Time-Weighted-Average (TWA) of 85 decibels (dB) is the limit for noise exposure recommended by the United States National Institute for Occupational Safety and Health [7]. However, noise levels above $75 \mathrm{~dB}$ over a long 
period of time, which can be present hatchery operations [6], can cause hearing impairment [8]. Negative physiological events, such as heart disease, elevated blood pressure, sleep disturbances, tinnitus, and hearing loss, can result from noise at levels as low as $55 \mathrm{~dB}$ [9] [10] [11] [12] [13]. A noisy environment can also lead to decreased work performance [14], particularly by interfering with verbal communication [15] [16]. Constant noise, as is particularly present with flowing water and pumps in aquaculture, makes speech even less intelligible than in conditions with fluctuating noise levels [17] [18] [19]. In addition to noise in aquaculture facilities potentially impacting human health and wellbeing, excessive noise may also be detrimental to the fish being produced [20] [21] [22] [23].

Barnes et al. [6] is the only published documentation of noise levels resulting from normal water flows in a production fish hatchery. Only two other studies directly reported occupational noise levels in areas related to aquaculture. Watterson et al. [24] described the noise levels associated with air blowers used in aquaculture, while Erondu and Anywanu [25] mentioned noise issues in aquaculture feed mills. The objective of this study was to determine noise levels in two different rearing buildings at an aquaculture facility, as well as document occupational noise levels resulting from tank cleaning operations.

\section{Methods}

This study was performed at Cleghorn Springs State Fish Hatchery in Rapid City, South Dakota. Noise levels were recorded using an Extech Instruments Digital Sound Level Meter Model 407732 (Extech Instruments Corp., Waltham, Massachusetts). The meter was calibrated at $94.0 \mathrm{~dB}$ using an Extech Instruments Sound Level Calibrator Model 407722, and set to the frequency weighting used by OSHA [26]. In addition, the meter was optimized to record noise levels between 35 and $100 \mathrm{~dB}$ by using a slow response time (one second) and a low setting [27]. This optimization was done to improve the accuracy of the meter within the hatchery environment, which tends to have droning sounds at fairly uniform decibel levels. The meter was held at an arm's length from the body during recordings to reduce any possible effects of sound reflected from the body [28]. Noise levels were recorded in both the hatchery tank room and rearing pavilion. Unless otherwise indicated, triplicate noise measurements were recorded at each sampling location.

\subsection{Tank Room}

The tank room layout is shown in Figure 1. The room dimensions are $23.0 \mathrm{~m}$ by $14.8 \mathrm{~m}$. The tank room has concrete floors and walls with ceramic block on the inside wall surface, and the roof is prefabbed concrete beams. All of the 32 fiberglass circular tanks are above ground, with water flowing into each tank through a $5.08 \mathrm{~cm}$-diameter spray bar. Each tank is $1.8 \mathrm{~m}$ in diameter and has a water depth of $76.2 \mathrm{~cm}$. The spray bars are located $5.1 \mathrm{~cm}$ above the water level in the tank. Each spray bar is $61.0 \mathrm{~cm}$ long with 11 evenly distributed holes. These 


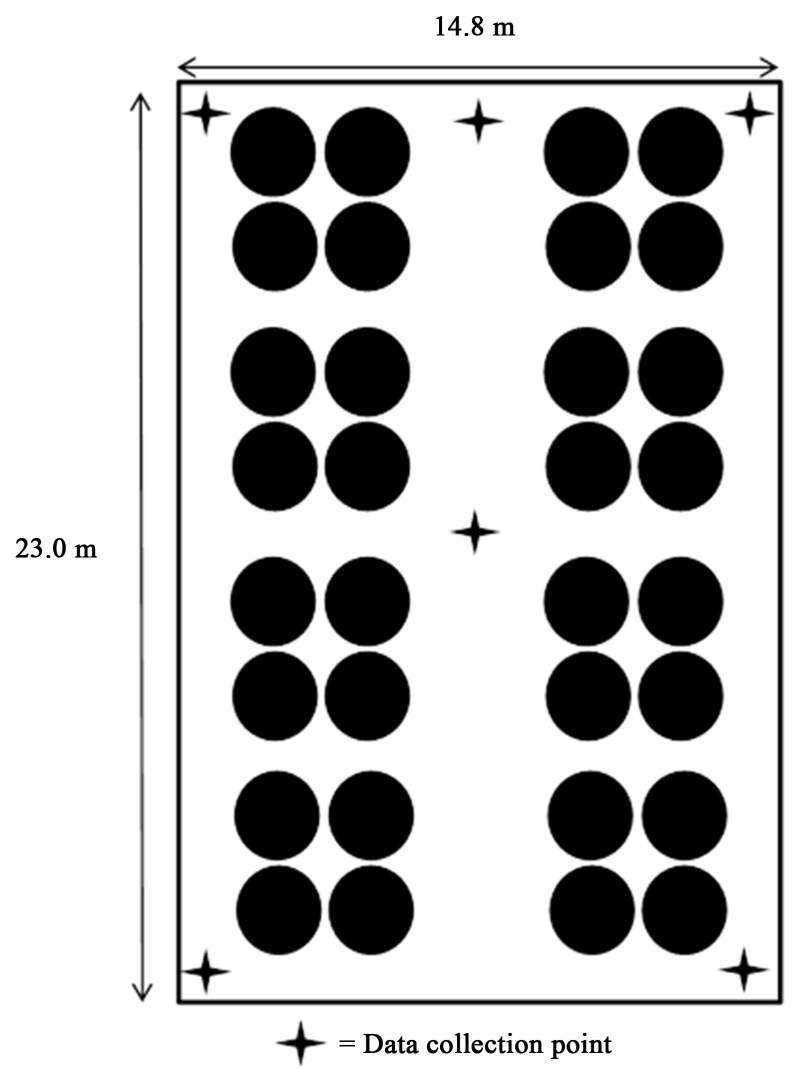

Figure 1. Schematic of the tank room at Cleghorn Springs State Fish Hatchery (not to scale). The large dark circles represent the rearing tanks. Points where noise readings were obtained are marked with four-pointed stars.

spray bars are set to a slight angle to keep water flowing in a circular fashion to make them self-cleaning [29]. Water levels are controlled by an external stand pipe, with one stand pipe per tank. Each $7.6 \mathrm{~cm}$-diameter stand pipe is $66 \mathrm{~cm}$ tall and is contained in a $17.1 \mathrm{~cm}$-diameter and $106.7 \mathrm{~cm}$-tall housing, which is open on the top to allow for cleaning. The water flows up through the stand pipe then falls approximately $140 \mathrm{~cm}$ to an open concrete trough that is set into the cement floor. For this study, water flows were set at normal operating conditions of 38.9 L/min, with tank water depths of $61.6 \mathrm{~cm}$. Each tank also had a plastic vibrating feeder (model \# AVF8; Pentair Aquatic Eco-Systems, Apopka, Florida) set 62.2 $\mathrm{cm}$ above the tank water level.

\subsection{Rearing Pavilion}

The rearing pavilion layout is depicted in Figure 2. The building is $62.8 \mathrm{~m}$ by $37.3 \mathrm{~m}$ with a wall height of $3.0 \mathrm{~m}$. The roof is peaked, with the peak falling 18.7 $\mathrm{m}$ from either wall. The floors are concrete, but the building is constructed of steel support beams and metal sheeting, with screen inlays along all walls for light, ventilation, and flood proofing the building. The in-ground, aluminum circular tanks in the pavilion are $6.1 \mathrm{~m}$ in diameter and $1.2 \mathrm{~m}$ tall, with operating water depths of $73.7 \mathrm{~cm}$. The spray bar for each tank is $1.2 \mathrm{~m}$ long and $11.4 \mathrm{~cm}$ 


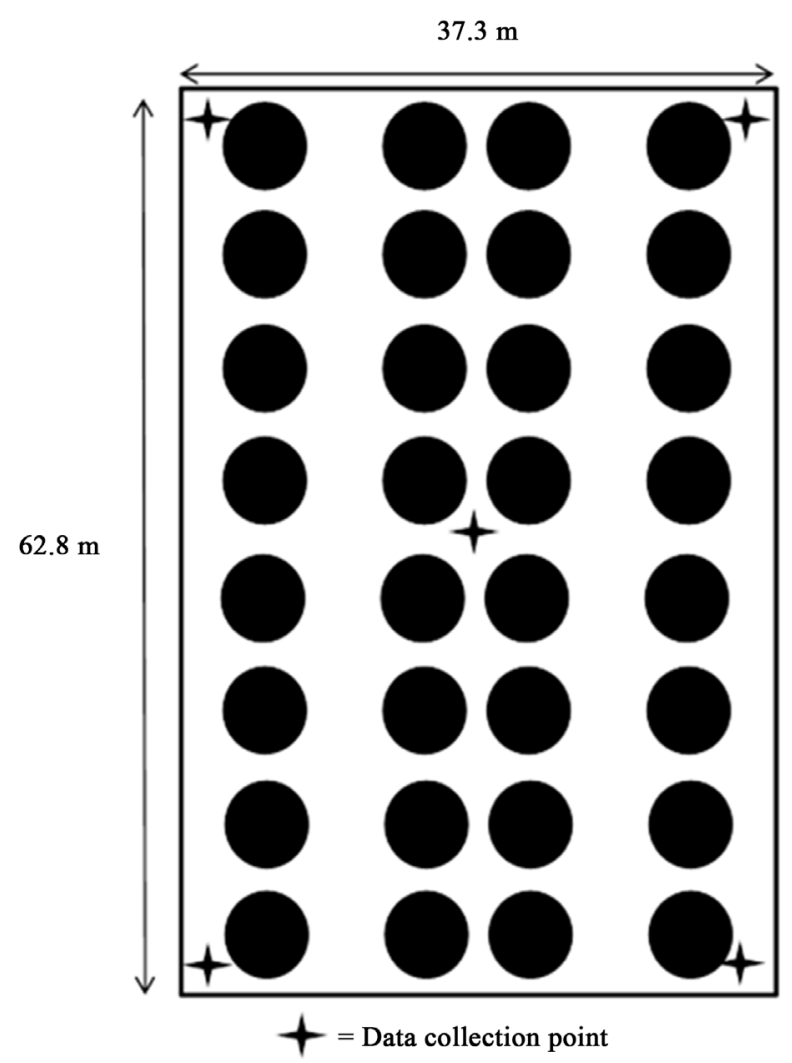

Figure 2. Schematic of the rearing pavilion at Cleghorn Springs State Fish Hatchery (not to scale). The large dark circles represent the rearing tanks. Points where noise readings were obtained are marked with four-pointed stars.

in diameter, with three discharge holes. Each spray bar is $10.2 \mathrm{~cm}$ above the water level, with water entering the tank at $5.1 \mathrm{~cm}$ above the water level. Every tank has an adjacent $16.5 \mathrm{~cm}$-diameter stand pipe is $1.1 \mathrm{~m}$ tall is located within an in-ground concrete cylinder ( $1.5 \mathrm{~m}$ in diameter, $1.7 \mathrm{~m}$ tall). Because noise data was collected during normal hatchery operations, the water inflow into each tank varied, ranging from $84.1 \mathrm{~L} / \mathrm{min}$ to $179.0 \mathrm{~L} / \mathrm{min}$.

\subsection{Sampling}

Baseline tank room data was collected on August 27, 2015. Because of a unique situation, no fish were present within the tank room on this date, allowing for the recording of noise levels in the absence of any flowing water. Noise levels were also recorded with water flowing to all of the tanks on February 28, 2017. On each date, noise measurements were taken at the same five locations, in each of the four corners and in the middle of the room. These locations were selected to represent noise levels throughout the room, and were based on those used by Barnes et al. [6]. Only one measurement was recorded at each location in 2015. To ascertain the effects of tank cleaning on noise levels, measurements were taken in between two tanks while they were being cleaned, as well as in the middle of the room. Noise levels were also recorded in the middle of the tank room 
when the electronic motors of the feeders were activated during feeding. All doors to the tank room were closed at time of noise measurement to reduce any possible effects of external noise.

Rearing pavilion data was collected on February 28, and March 1, 2017. Noise measurements in the pavilion without any running water could not be obtained because hatchery production required that tanks be in use throughout the year. Noise levels were again recorded in five different locations, at each corner of the building and approximately in the middle. At each location noise was recorded under two different scenarios: during normal production levels (all tanks running) and during power washing of tanks. In addition, noise readings were recorded above the standpipe sumps and adjacent to the power washer while it was in operation.

\subsection{Data Analysis}

Within each rearing building, mean $\mathrm{dB}$ levels under each scenario were obtained by averaging readings from each sampling location. Data for each building was analyzed with one-way analysis of variance, with Tukey's HSD test used if there was a significant difference among the treatments [30]. All data analysis was done using SPSS (9.0) statistical analysis program (SPSS, Chicago, Illinois), with significance predetermined at $P<0.05$.

\section{Results}

Tank room noise levels significantly varied depending on water flows, feeder operations, and tank cleaning $\left(\mathrm{F}_{4,24}=669.355, \mathrm{P}=0.000\right)$. With no water flowing in tank room, the mean ambient noise level was $36.1 \mathrm{~dB}$ (Table 1). Noise levels increased to over $68 \mathrm{~dB}$ with water flowing to all of the tanks, and significantly increased again when the feeders were running or the tanks were cleaned. The highest mean tank room noise values of $73 \mathrm{~dB}$ were obtained by the drains during tank cleaning.

Table 1. Mean (SD) dB measurements from two hatchery buildings and multiple operating scenarios. Within each location, means with different letters are significantly different $(P<0.05)$.

\begin{tabular}{cccc}
\hline Location & Treatment & $\mathrm{N}$ & $\mathrm{dB}$ \\
\hline Tank room & No water flow & 5 & $36.1(1.7) \mathrm{w}$ \\
& Flow to all tanks & 15 & $68.4(1.5) \mathrm{x}$ \\
& Tank cleaning (center of room) & 3 & $73.0(0.8) \mathrm{y}$ \\
Tank cleaning (by tanks) & 3 & $77.1(0.8) \mathrm{z}$ \\
Rearing pavilion & Noeders running & 3 & $73.2(0.8) \mathrm{y}$ \\
& Power washing tanks & 15 & $70.2(3.1) \mathrm{x}$ \\
& Power washer & 15 & $76.1(2.3) \mathrm{y}$ \\
& Tank sumps & 3 & $83.2(2.1) \mathrm{z}$ \\
& & 3 & $77.8(1.7) \mathrm{yz}$ \\
\hline
\end{tabular}


Rearing pavilion noise levels also varied significantly $\left(\mathrm{F}_{3,32}=26.658, P=\right.$ 0.000). During normal operations with water flowing to all of the tanks, the mean noise level was $70.2 \mathrm{~dB}$. Noise was significantly higher during power washing of the tanks and above the tank sumps which contained the standpipes. The highest mean pavilion noise values were recorded adjacent to the power washer at over $83 \mathrm{~dB}$.

\section{Discussion}

The noise levels obtained observed in this study are lower than those reported at another fish hatchery with similar infrastructure by Barnes et al. [6]. For example, with water flowing to all of the circular tanks in the Cleghorn Hatchery tank room, noise levels were $68 \mathrm{~dB}$ compared to the $73 \mathrm{~dB}$ with water running to all of the similarly-sized circular tanks in the Barnes et al. [6] study. This difference is likely due to three fewer tanks in the Cleghorn Hatchery tank room, as well as the larger dimensions compared to the tank room examined by Barnes et al. [6]. Building size can affect noise levels [24]. Noise levels in the rearing pavilion were also considerably less than that reported by Barnes et al. [6] for a similarly-constructed building (in-ground circular tanks, steel beams and siding, open mesh, etc.). However the pavilion at the Cleghorn Hatchery is much larger, with greater diameter and more numerous tanks (32 versus 6). The differences in noise levels between the hatcheries and also between the buildings within Cleghorn Hatchery is to be expected given the different building dimensions and construction materials [31] [32] as well as differences in the number and size of tanks and standpipes [33] [34].

Nelson et al. [11], NIOSH [7], and OSHA [26] all recommend a noise exposure limit of $85 \mathrm{~dB}$ to prevent physiological damage. The noise values in this study are all below that limit, with only the mean value of $83 \mathrm{~dB}$ taken in close proximity to the rearing pavilion power washer approaching the level associated with hearing loss. However, even the lower noise levels from the tank room and rearing pavilion may lead to other adverse effects such as elevated blood pressure, reduced performance, sleeping difficulties, annoyance, stress, and temporary threshold shift [8] [11] [12] [14]. The European Agency for Safety and Health at Work [12] lists annoyance occurring at noise levels of $60 \mathrm{~dB}$, the appearance of stress effects at $65 \mathrm{~dB}$, sleep disturbances at $70 \mathrm{~dB}$, adverse cardiovascular effects at $75 \mathrm{~dB}$, and hearing loss or tinnitus at $85 \mathrm{~dB}$. Thus, the values reported during tank room tank cleaning (73 to $77 \mathrm{~dB}$ ) and pavilion power washing ( 76 to $83 \mathrm{~dB}$ ) may be of particular concern.

With the exception of noise levels during cleaning (which typically occurs one tank at a time), the low amount of variation in noise levels among the sampling points in each building indicates the absence of any positional effect. In addition, because water is continuously flowing to the tanks and subsequently through the open stand pipes, there is likely little change in noise levels throughout the day as well. Therefore, the values obtained in this study should represent the likely exposure of hatchery workers to occupational noise while they are in the tank 
room or rearing pavilion, except when tanks are being cleaned or during other aquacultural operations such as fish moving. While at Cleghorn Hatchery such actions are relatively brief (cleanings in the tank room are typically once a day for only an hour or so, and the pavilion tanks are pressure washed once a week), other aquaculture facilities may have different schedules or rearing philosophies [28], thereby making generalizations about noise exposure somewhat speculative.

In conclusion, the hatchery noise levels recorded in this study were not at a regulatory level requiring hearing protection [7]. However, such protection may still be a good idea when in hatchery buildings, particularly during tank cleaning or other non-routine culture activities. In addition, the use of techniques to reduce occupational noise in aquaculture environments, such as stand pipe covers or partial tank covers [6], is advisable.

\section{Acknowledgements}

We thank Brian Fletcher, Cody Treft, and Tabor Martin for their assistance with this study.

\section{References}

[1] Simpson, M. and Bruce, R. (1981) Noise in America: The Extent of the Noise Problem. U.S. Environmental Protection Agency, EPA Report 550-9-81-101.

[2] Moreau, D.T.R. and Neis, B. (2009) Occupational Health and Safety Hazards in Atlantic Canadian Aquaculture: Laying the Groundwork for Prevention. Marine Policy, 33, 401-411. https://doi.org/10.1016/j.marpol.2008.09.001

[3] Douglas, J.D.M. (1995) Salmon Farming: Occupational Health in a New Rural Industry. Occupational Medicine, 45, 89-92. https://doi.org/10.1093/occmed/45.2.89

[4] Myers, M.L. and Cole, H.P. (2009) Simple Solutions for Reduced Fish Farm Hazards. Journal of Agromedicine, 14, 150-156. https://doi.org/10.1080/10599240902721024

[5] Myers, M.L. and Durborow, R.M. (2012) Aquaculture Safety and Health. In: Carvalho, E., Ed., Health and Environment in Aquaculture, InTech, Rijeka, Croatia.

[6] Barnes, M.E., Hewitt, C.R. and Parker, T.M. (2015) Fish Hatchery Noise Levels and Noise Reduction Techniques. Journal of Agricultural Safety and Health, 21, 187195.

[7] National Institute for Occupational Safety and Health (NIOSH) (1998) Criteria for Recommended Standard Occupational Noise Exposure. United States Department of Health and Human Services, National Institute for Occupational Safety and Health Publication, Cincinnati, Ohio, 98-126.

[8] Passchier-Vermer, W. and Passchier, W.F. (2000) Noise Exposure and Public Health. Environmental Health Perspectives, 108, 123-131.

https://doi.org/10.1289/ehp.00108s1123

[9] Stansfeld, S.A. and Matheson, M.P. (2003) Noise Pollution: Non-Auditory Effects on Health. British Medical Bulletin, 68, 243-257.

https://doi.org/10.1093/bmb/ldg033

[10] Ising, H. and Kruppa, B. (2004) Health Effects Caused by Noise: Evidence in the Literature from the Past 25 Years. Noise and Health, 6, 5-13.

http://www.noiseandhealth.org/text.asp?2004/6/22/5/31678 
[11] Nelson, D.I., Nelson, R.Y., Concha-Barrientos, M. and Fingerhut, M. (2005) The Global Burden of Occupational Noise-Induced Hearing Loss. American Journal of Industrial Medicine, 48, 446-458. https://doi.org/10.1002/ajim.20223

[12] European Agency for Safety and Health at Work (2005) Noise in Figures. https://osha.europa.eu/en/tools-and-publications/publications/reports/6905723

[13] Selander, J., Nilsson, M.E., Bluhm, G., Rosenlund, M., Lindqvist, M., Nise, G. and Pershagen, G. (2009) Long-Term Exposure to Road Traffic Noise and Myocardial Infraction. Epidemiology, 20, 272-279. https://doi.org/10.1097/EDE.0b013e31819463bd

[14] Melamed, S., Lux, J. and Green, M.S. (1991) Noise Exposure, Noise Annoyance and their Relation to Psychological Distress, Accident and Sickness Absence Among Blue-Collar Workers-The Cordis Study. Israeli Journal of Medical Science, 28, 629-635.

[15] Houtgast, T. (1981) The Effects of Ambient Noise on Speech Intelligibility in Classrooms. Applied Acoustics, 14, 15-25. https://doi.org/10.1016/0003-682X(81)90040-2

[16] Rhebergen, K.S. and Versfeld, N.J. (2005) A Speech in Intelligibility Index-Based Approach to Predit the Speech Reception Threshold for Sentences in Fluctuating Noise for Normal-Hearing Listeners. Journal of the Acoustical Society of America, 117, 2181-2192. https://doi.org/10.1121/1.1861713

[17] Versfeld, N.J. and Dreschler, W.A. (2002) The Relationship between the Intelligibility of Time-Compressed Speech and Speech in Noise in Young and Elderly Listeners. Journal of the Acoustical Society of America, 111, 401-408. https://doi.org/10.1121/1.1426376

[18] Dubno, J.R., Horwitz, A.R. and Ahlstrom J.B. (2002) Benefit of Modulated Maskers for Speech Recognition by Younger and Older Adults with Normal Hearing. Journal of the Acoustical Society of America, 111, 2897-2907. https://doi.org/10.1121/1.1480421

[19] Nelson, P.B., Jin, S.H., Carney, A.E. and Nelson, D.A. (2003) Understanding Speech in Modulated Interference: Cochlear Implant Users and Normal-Hearing Listeners. Journal of the Acoustical Society of America, 113, 961-968. https://doi.org/10.1121/1.1531983

[20] Varanasi, U., Casillas, E., Arkoosh, M.R., Hom, T., Misitano, D.A., Brown, D.W., Chan, S.-L., Collier, T.K., McCain, B.B. and Stein, J.E. (1993) Contaminant Exposure and Associated Biological Effects in juvenile Chinook Salmon (Oncorhunchustsawytshcha) from Urban and Nonurban Estuaries in Puget Sound. National Marine Fisheries Service, NOAA Technical Memorandum NMFS-NWFSC-8, Seattle, Washington DC.

[21] Oxman, D.S., Barnett-Johnson, R., Smith, M.E., Coffin, A., Miller, D.L., Josephson, R. and Popper, A.N. (2007) The Effect of Vaterite Deposition on Sound Reception, Otolith Morphology, and Inner Ear Sensory Epithelia in Hatchery-reared Chinook Salmon (Oncorhynchus tshawytscha). Canadian Journal of Fisheries and Aquatic Science, 64, 1469-1478. https://doi.org/10.1139/f07-106

[22] Davidson, J., Bebak, J. and Mazik, P. (2009) The Effects of Aquaculture Production Noise on the Growth, Condition Factor, Feed Conversion, and Survival of Rainbow Trout, Oncorhynchus mykiss. Aquaculture, 288, 337-343. https://doi.org/10.1016/j.aquaculture.2008.11.037

[23] Slabbekoorn, H. (2016) Aiming for Progress in Understanding Underwater Noise Impact on Fish: Complementary Need for Indoor and Outdoor Studies. In: Popper, A., Ed., Advances in Experimental Medicine and Biology. The Effects of Noise on Aquatic Life II, Springer, New York, 1057-1065. 
https://doi.org/10.1007/978-1-4939-2981-8_131

[24] Watterson, A., Little, D., Young, J.A., Murray, F., Doi, L., Boyd, K.A. and Azim, E. (2012) Scoping a Public Health Impact Assessment of Aquaculture with Particular Reference to Tilapia in the UK. International Scholarly Research Network Public Health, 2012, Article ID: 203796, 18 p.

[25] Erondu, E.S. and Anayanwu, P.E. (2005) Potential Hazards and Risks Associated with the Aquaculture Industry. African Journal of Biotechnology, 37, 471-484.

[26] Occupational Safety and Health Administration (OSHA) (2017) 1910.95: Occupational Noise Exposure.

https://www.osha.gov/pls/oshaweb/owadisp.show_document?p_table=STANDARD $\underline{\text { S\&p_id }=9735}$

[27] Extech (2014) Digital Sound Level Meter User's Guide: 407732-EN-V1.5. Extech Instruments, Walthman, Massachusetts.

[28] Mine Safety and Health Administration (MSHA) (2000) A Guide to Conducting Noise Sampling. https://arlweb.msha.gov/1999noise/ig32.pdf

[29] Parker, T.M. and Barnes, M.E. (2014) Rearing Velocity Impacts on Landlocked Fall Chinook Salmon (Oncorhynchus tshaqytscha) Growth, Condition, and Survival. Open Journal of Animal Sciences, 4, 244-252. https://doi.org/10.4236/ojas.2014.45031

[30] Kuehl, R.O. (2000) Design of Experiments: Statistical Principles of Research Design and Analysis. 2nd Edition, Brookes/Cole, Pacific Grove, California.

[31] Harris, C.M. (1994) Noise Control in Buildings: a Guide for Architects and Engineers. McGraw-Hill, New York.

[32] DeSalis, M.H.F., Oldham, D.J. and Sharples, S. (2002) Noise Controls Strategies for Naturally Ventilated Buildings. Building and Environment, 37, 471-484.

https://doi.org/10.1016/S0360-1323(01)00047-6

[33] Hopkins, C. (2007). Sound Insulation. Elsevier, Oxford.

[34] Trushenski, J.T., Flagg, T. and Kohler, C.C. (2010) Use of Hatchery Fish for Conservation, Restoration, and Enhancement of Fisheries. In: Hubert, W. and Quist, M., Eds., Inland Fisheries Management in North America, 3rd Edition, American Fisheries Society, Bethesda, Maryland.

Submit or recommend next manuscript to SCIRP and we will provide best service for you:

Accepting pre-submission inquiries through Email, Facebook, LinkedIn, Twitter, etc. A wide selection of journals (inclusive of 9 subjects, more than 200 journals)

Providing 24-hour high-quality service

User-friendly online submission system

Fair and swift peer-review system

Efficient typesetting and proofreading procedure

Display of the result of downloads and visits, as well as the number of cited articles

Maximum dissemination of your research work

Submit your manuscript at: http://papersubmission.scirp.org/

Or contact odem@scirp.org 